\title{
Measurement of Photosynthetic Rate of a Cultured Benthic Blue-green Alga: Tolypothrix sp.
}

\author{
CHEN Yuwei ${ }^{1} \quad$ Martin Dokulil ${ }^{2}$ \\ (1: Nanjing Institute of Geography and Limnology, Nanjing 210008, P. R. China ; \\ 2: Institute of Limnology, A-5310 Mondsee. Austria)
}

\begin{abstract}
Photosynthesis of a cultured benthic blue-green alga Tolypothrix sp. was measured under light and temperature conditions using oxygen light-dark bottle method and ${ }^{14} \mathrm{C}$ light-dark bottle method. Respiratory rates of the alga were also measured at different temperatures. Photosynthetic rates increased with increasing temperatures. Respiratory rates did not show significant differences among different temperatures. Photosynthetic rates were almost the same under light intensities lower than 400 $\mu \mathrm{Em}^{-2} \mathrm{~s}^{-1}$. Comparing the oxygen and ${ }^{14} \mathrm{C}$ method, the photosynthetic quotient $\mathrm{Q}$ (moles $\mathrm{O}_{2}$ per moles C) of Tolypothrix sp. in these experiments was about 1.11 . The method for the measurement of photosynthesis of such kind of benthic alga was improved in this paper.
\end{abstract}

Key Words Tolypothrix sp., benthic alga, photosynthesis, temperature

Photosynthesis of planktonic algae which are major primary producers in aquatic ecosystems is an important basis of production in the ecosystems ${ }^{[1]}$. Thus much attention has been focused on the studies of photosynthesis of phytoplankton from an ecological point of view. The measurement of primary production based on the photosynthesis of phytoplankton has already become one of the principal subjects for oceanographers as well as limnologists ${ }^{[2.3]}$. When the $\mathrm{O}_{2}$ and ${ }^{14} \mathrm{C}$ light and dark bottle techniques were applied, several assumptions were, however, necessary for interpretation of the results, and these are still open to much discussion ${ }^{[4-6]}$.

In short time experiments a good agreement between gross oxygen production and carbon uptake, calculated from ${ }^{14} \mathrm{C}$ uptake, is usually found ${ }^{[7,8]}$.

Most of these studies dealt with planktonic matter. There are very few research focusing on benthic alage, especially on benthic blue-green algae. In many shallow lakes as well as small rivers, the benthic algae are the major primary producers. In the large, shallow Borax Lake of northern California, epiphytic algae are the major source of organic matter. Because the littoral area is small, the attached alga-contribution is reduced but still constitutes nearly one-half of total primary productivity. In Marion Lake the primarily epiphytic algae dominate the lake system ${ }^{[9]}$. Therefore the measurement of photosynthesis of benthic algae become more interesting for the aquatic ecosystem studies $^{[10]}$.

Tolyporthrix sp. is a benthic filamentous blue-green alga and a good food source of zoob-

* Received: $1997-08-06$; accepted: $1998-03-10$. CHEN Yuwei, male, born in 1969, assistant researcher. 
enthos such as Ostracodes. ${ }^{[11]}$ But, once it is cultured in the laboratory, it becomes big colony and can hardly be separated. The methodological problems for measuring the photosynthetic rates of this alga are presented. This study intends to improve the method and try to find the relationship between photosynthetic rates and light intensity and temperature of this alga.

\section{Material and Methods}

Tolypothrix sp. were cultured at $20^{\circ} \mathrm{C}$ and at a light condition of about $200 \mu \mathrm{Em}^{-2} \mathrm{~s}^{-1}$ in the laboratory. The component of the culture medium is shown below:

First Step: Preparation of 8 stock solutions

\begin{tabular}{|c|c|}
\hline Solution & Concentration $\left(\mathrm{g} \cdot \mathrm{L}^{-1}\right)$ \\
\hline 1. &. $\mathrm{~K}_{2} \mathrm{HPO}_{4} \ldots \ldots \ldots$ \\
\hline 2. & $\ldots \mathrm{MgSO}_{4} \cdot 7 \mathrm{H}_{2} \mathrm{O} \ldots \ldots \ldots \ldots$ \\
\hline $3 \ldots$ & $\ldots \mathrm{Na}_{2} \mathrm{HCO}_{3} \ldots \ldots$ \\
\hline $4 \ldots$ & $\ldots$ Citric acid. . . . . . \\
\hline $5 \ldots$ & $\ldots \mathrm{CaCl}_{2} \cdot 2 \mathrm{H}_{2} \mathrm{O} \ldots \ldots \ldots \ldots \ldots \ldots$ \\
\hline $6 \ldots$ & $\ldots$ Ferric ammonium citrate . . . . . . 50 \\
\hline $7 \ldots$ & $\ldots$ EDTA $-\mathrm{Na}_{2} \ldots \ldots \ldots$ \\
\hline \multicolumn{2}{|c|}{$8 \ldots \ldots \ldots$ Microelements solution } \\
\hline & $\mathrm{H}_{3} \mathrm{BO}_{3} \ldots \ldots \ldots$ \\
\hline & $\mathrm{MnCl}_{2} \cdot 4 \mathrm{H}_{2} \mathrm{O} \ldots$ \\
\hline & $\mathrm{ZnSO}_{4} \cdot 7 \mathrm{H}_{2} \mathrm{O} \ldots \ldots \ldots \ldots \ldots .222$ \\
\hline & $\mathrm{Na}_{2} \mathrm{MoO}_{4} \cdot 2 \mathrm{H}_{2} \mathrm{O} \ldots \ldots \ldots \ldots .39$ \\
\hline & $\mathrm{CuSO}_{4} \cdot 5 \mathrm{H}_{2} \mathrm{O} \ldots \ldots \ldots \ldots \ldots .079$ \\
\hline & $\mathrm{Co}\left(\mathrm{NO}_{3}\right)_{2} \cdot 6 \mathrm{H}_{2} \mathrm{O} \ldots \ldots \ldots$ \\
\hline
\end{tabular}

Second Step: Preparation of $1 \mathrm{~L}$ of Mother Solution

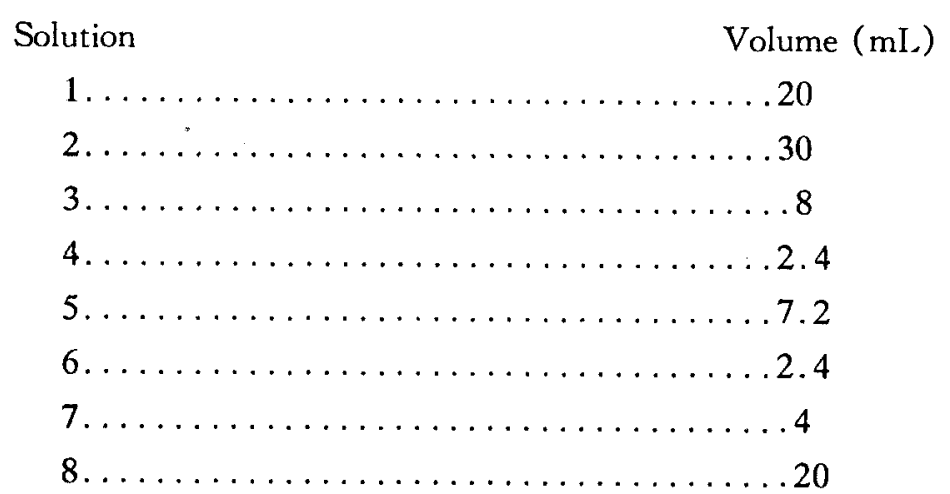

Third Step: Preparation of $1 \mathrm{~L}$ of algal culture medium

- Use $100 \mathrm{~mL}$ of Mother Solution

- Use $50 \mathrm{~mL}$ of old algal solution 
- USe $850 \mathrm{~mL}$ of distilled water

The big colonies (about $3 \mathrm{~mm}$ in diameter) were used in the experiment. Several pre-experiments were carried out for determining the alga biomass and choose the experimental conditions:

(1) Fresh weight and dry weight correlation: Ten groups of colonies (from one to ten colonies) which have almost same size were picked out. For the fresh weight determination, single colonies were dipped shortly on filter paper to remove adherent water and then weighted quickly on a Mettler ME22 balance. Dry weight was measured after drying at $50^{\circ} \mathrm{C}$ for one hour. The correlation between fresh weight and dry weight was calculated.

(2) Fresh weight and chlorophyll a correlation: Ten groups of colonies (from one colony to ten colonies) which have almost same size were picked out. After the fresh weight determination, chlorophyll a was measured $\left(90 \%\right.$ hot ethanol) ${ }^{[2]}$. The correlation between fresh weight and chlorophyll a. was calculated.

(3) Pre-experiments for comparing the filtered lake water and culture medium and choosing the number of colonies for experiment: Oxygen light bottles were used in these pre-experiments. Two initial bottles, two light bottles with lake water filtered through $1 \mu \mathrm{m}$ net and two with culture medium were prepared for comparing the medium and the lake water. After adding alga colonies and exposing for three hours, the oxygen was determined by Winkler technique. Two initial and three light bottles (with 3 colonies, 7 colonies and 11 colonies) were used for choosing a suitable colony number. The rest of the procedures was the same as above.

The oxygen light-dark bottle method was used for measuring photosynthesis and respiration ( $58.5 \mathrm{~mL}$ Jenaer glass bottle). The ${ }^{14} \mathrm{C}$ light-dark bottle method was used for measuring carbon uptake at the same time $\left(38 \mathrm{~mL}\right.$ Jenaer glass bottle). Five different temperatures $\left(5^{\circ} \mathrm{C}, 10^{\circ} \mathrm{C}\right.$, $\left.15^{\circ} \mathrm{C}, 20^{\circ} \mathrm{C}, 25^{\circ} \mathrm{C}\right)$ and six different light intersities $\left(45,90,140,210,260\right.$, and $\left.410 \mu \mathrm{Em}^{-2} \mathrm{~s}^{-1}\right)$ were selected for the experiments (Four $40 \mathrm{~W}$ fluorescent lamps were used as light source). In the incubator, three different light intensities either 46,140 and $210 \mu \mathrm{Em}^{-2} \mathrm{~s}^{-1}$ or 90,260 and 410 $\mu \mathrm{Em}^{-2} \mathrm{~s}^{-1}$ were set at a time for each temperature. Each time, two oxygen initial bottles, two oxygen dark bottles, three ${ }^{14} \mathrm{C}$ light bottles (each light intensity one light bottle) and one ${ }^{14} \mathrm{C}$ dark bottle were used. The main experiments were carried out with the following procedure:

(1) Fill filtered lake water $\left(1 \mu \mathrm{m}\right.$ net) to the bottles, add ${ }^{14} \mathrm{C}$ solution $(4 \mu \mathrm{Ci}$ per bottle) to the ${ }^{14} \mathrm{C}$ light and dark bottles. Another $100 \mathrm{~mL}$. water was used for measuring $\mathrm{pH}$ and alkalinity.

(2) Pick out alga colonies from the culture medium (about 8 colonies per bottle), measure the fresh weights and add the colonies to each bottle.

(3) Expose the bottles in the incubator for 3 hours.

(4) After exposure, the algae in the ${ }^{14} \mathrm{C}$ experiment bottles were filtered through $0.22 \mu \mathrm{m}$ Sartorial cellulose acetate filter, then use 1600-TR. Liquid Scintillation Analyzer to count the radioactivity. Use Winkler method $\left(0.005 \mathrm{~N} \mathrm{Na}_{2} \mathrm{~S}_{2} \mathrm{O}_{3}\right)$ to titrate dissolved oxygen.

(5) Calculate the photosynthetic and respiratory rate from oxygen method and the carbon up- 
take rate from ${ }^{14} \mathrm{C}$ method. Compare the results of these two techniques.

\section{Results}

Relationship between fresh weight and dry weight, fresh weight and chlorophylla are presented in Figure 1a, 1b. Both of the figures showed a good relationship $\left(r^{2}>0.96\right)$. So, it is possible to use the fresh weight or dry weight for this filamentous colonial algae as the basis for the following measurements.
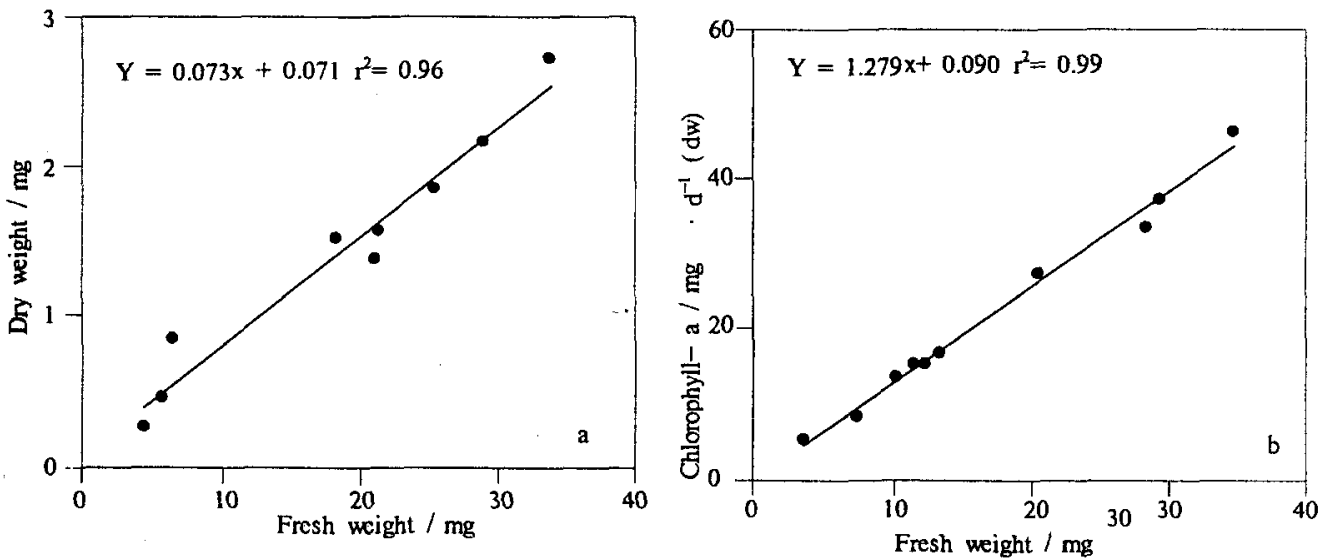

Fig. 1 Regressions between fresh weight and dry weight(a) and between fresh weight and Chlorophyll-a (b)

Results of pre-experiment No. 3 are shown in Tab.1. It appears that using filtered lake water is better than using medium. Seven or more colonies are suitable for the experiments.

Tab. 1 Results of pre-experiments to choose experimental conditions of Tolypothrix sp.

\begin{tabular}{lccccc}
\hline Items & $\begin{array}{c}\text { Ini. bot. } \\
\left./ \mathrm{mgO}_{2} \cdot \mathrm{L}^{-1}\right)\end{array}$ & $\begin{array}{c}\text { Light bot. } \\
\left./ \mathrm{mgO}_{2} \cdot \mathrm{L}^{-1}\right)\end{array}$ & $\begin{array}{c}\text { Freshweight } \\
(\mathrm{mg})\end{array}$ & $\begin{array}{c}\text { Dryweight } \\
/ \mathrm{mg}\end{array}$ & $\begin{array}{c}\mathrm{P} / \mathrm{B} \mathrm{Ratio} \\
/ \mathrm{mgO}_{2} \cdot \mathrm{mg}^{-1}(\mathrm{DW})\end{array}$ \\
\hline lake & 7.99 & 8.685 & 11.732 & 0.921 & 0.755 \\
water & & 8.69 & 13.105 & 1.021 & 0.686 \\
Culture & 5.79 & 5.97 & 10.588 & 0.838 & 0.215 \\
Medium & & 6.05 & 10.868 & 0.859 & 0.303 \\
& Initial & Light bottle 3 & Light bottle & light bottle & \\
& bottle & colonies & 7 colonies & 11 colonies & \\
$\mathrm{O}_{2} / \mathrm{mg} \cdot \mathrm{L}^{-1}$ & 7.32 & 7.57 & 8.32 & 8.44 & \\
\hline
\end{tabular}

Photosynthesis-light curves of Tolypothrix sp. constructed for different temperatures are shown in Figure 2. From both oxygen and the ${ }^{14} \mathrm{C}$ results, the photosynthetic rates are almost the same under different light intensities (from 46 to $410 \mu \mathrm{Em}^{-2} \mathrm{~s}^{-1}$ ) in each temperature, although there is more $\mathrm{fl}$ uctuation at high temperature than at low temperatures. No light inhibiation occurred at the highest light intensity used. Respiratory rates from the oxygen measurements were not significant different in each temperature $\left(r^{2}=0.2018\right.$, Figure 3$)$. From the oxygen 

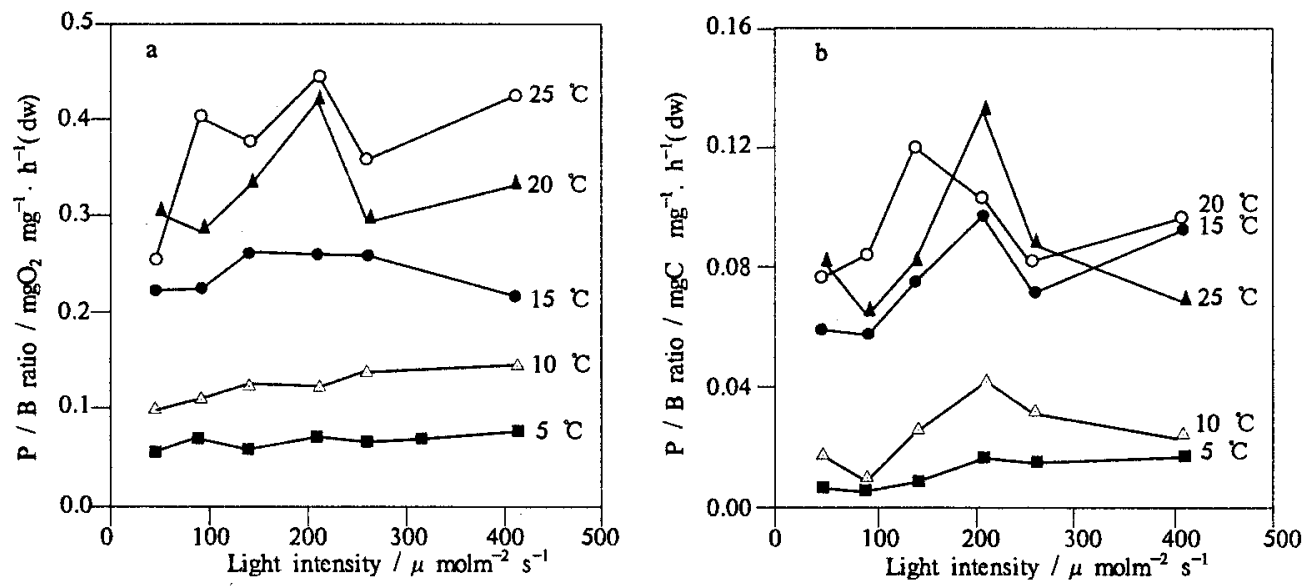

Fig. 2 Photosynthesis-light curves of Tolypothrix sp. (a. Oxygen output, b. Carbon uptake) gross photosynthetix rates, it can be seen that higher rates was obtained as temperature increased.

Photosynthesis-temperature curves (Figure 4) constructed at different light intensities also show that the $\mathrm{P} / \mathrm{B}$-ratio increase with increasing temperature. There is no big difference in each light intensity.

The regression between oxygen method (Oxygen output) and ${ }^{14} \mathrm{C}$ method (carbon uptake) is presented in Figure 5. From the result, it seems that carbon uptake for measuring photosynthesis is closed to oxygen gross production $\left(\mathrm{r}^{2}=0.77\right)$. The photosynthetic quotient $\mathrm{Q}$, defined as oxygen output divided by carbon uptake (moles $\mathrm{O}_{2}$ per moles C), is about 1.11 in these experiments.

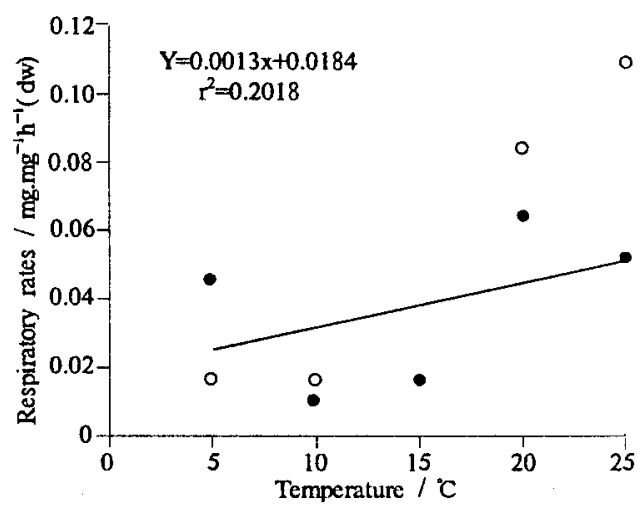

Fig. 3 Regression between respiratory rates and temperature of Tolypothrix sp.

\section{Discussion}

As Tolypothrix sp. is a benthic blue-green alga, the photosynthetic rhythm is different as the planktonic algae. From the description of Wetzel ${ }^{[9]}$, productivity values of littoral alage are difficult to compare from one lake to another, or even seasonally within a lake, because of the diversity of techniques employed. Thus, the results of this study are also difficult to compare with other cultured studies such as Aruga ${ }^{[1]}$. The methods used in the experiments are relatively new and a lot of technique problem appeared during the experiments. For example, from the pre-experiment results it seems that it is possible to use the fresh weight as the basic biomass for comparison but it is very difficult to handle the weighing of fresh weight of Tolypothrix sp. The fluctua- 


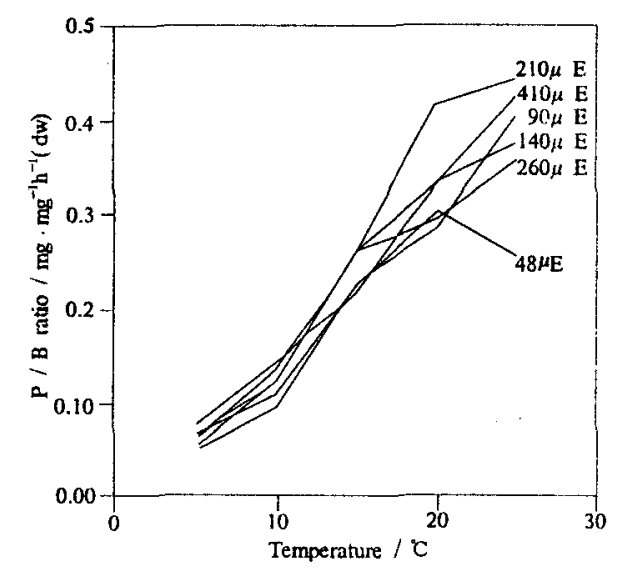

Fig. 4 Photosynthesis-temperature curves of Tolypothrix sp. (Oxygen output)

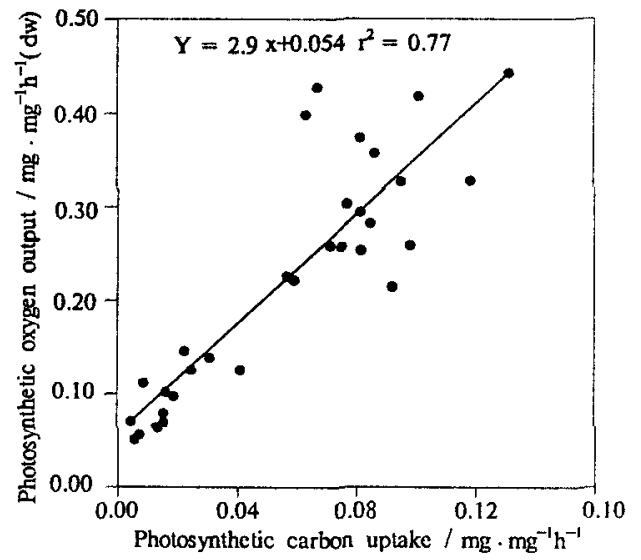

Fig. 5 Regression between oxygen output and carbon uptake of Tolypothrix sp.

tion of the results in this experiment might be because of the difference of specific activity of alage changing during the culture. It was not so easy to find alga material of the same specific activity for the experiments methodological problems effect the results.

The photosynthetic rates are almost the same under different light intensities because the light intensities used in the experiments were not ligh enough to saturate photosynthesis. Light intensity of natural day-light is about $2500 \mu \mathrm{Em}^{-2} \mathrm{~s}^{-1}$. It is noteworthy, as Kann points out, that Tolypothrix is a typically genera of streams ${ }^{[9]}$. Normally, high light intensity can be found in streams. Therefore, Tolypothrix sp. may be regarded as a high light intensity species.

From the photosynthesis-temperature curves (Figure 4), it is clear that temperature is a major factor controlling photosynthesis of Tolypothrix sp.

Respiration of Tolypothrix sp. in these experiments seem to be rather high (about $6 \%-$ $35 \%$ ) when compared with results from natural phytoplankton or laboratory culture. ${ }^{[2,12]}$ The reason could be, that respiration is higher in benthic algae than in phytoplankton, as Straskraba (1970) observed. ${ }^{[9]}$

The photosynthetic quotient $\mathrm{Q}$ (moles $\mathrm{O}_{2}$ per moles C) theoretically should be 1 but in these experiments, it was about 1.11 similar to observations from cultures of Selenatrum capricornutum at low light intensities $(Q=1.14-1.35)$. ${ }^{[12\}}$

Acknowledgments We wish to thank Claudia Skolaut who helps us in various ways during the experiment. Out thanks are extended to all the people in the Institute of Limnology in Mondsee, Austria, especially to Dr. Franz Neidl and Annemarie Henning for their help.

\section{References}

1 Aruga Yusho. Ecological studies of photosynthesis and matter production of phytoplankton (I): Seasonal changes in photosyn- 
thesis of natural phytoplankton. Bot Mag Tokyo, 1965, 78:360-365

2 Dokulil M T. Assessment of components controlling phytoplankton photosynthesis and bacteriplankton production in a shallow, alkaline, turbid lake (Neusiedlersee, Austria). Int Revue Ges Hylrobiol, 1984, 69:679-727

3 Gentner S R. Measurement of primary productivity in dense algae cultures. Can J Fish Aquat Sci, 1983, 40:807-810

4 Fogg G E. Oxygen-versus ${ }^{14} \mathrm{C}$ methodology. In: Vollenweider R A, ed. A manual on methods for measuring primary production in aquatic environments. IBP handbook No.12, Oxford: Blackwell, 1969. 95-97

5 Goldman $\mathrm{C}$ R, et al. The ${ }^{14} \mathrm{C}$ light and dark bottle technique. In: Vollenweider R A, ed. A manual on methods for measuring primary production in aquatic environments. IBP Handbook No. 12, Oxford: Blackwell, 1969.70-73

6 Talling J F. Primary production of freshwater microphytes. In: Cooper J P ed. Photosynthesis and productivity in different environments. Cambridge: Cambridge University Press, 1975.225-247

7 Fott J. Observations on primary production of phytoplankton in two fish ponds. In: Kajak $Z$ \& Hillbricht Ilkowska A, eds. Productivity problems of freshwater. Proceedings of the IBP-UNESCO Symposium on productivity problems of freshwater, Warszawa, Krakow, 1972.673-683

8 Jewson D H. A comparison between in in situ photosynthesis rates determined using ${ }^{14} \mathrm{C}$ uptake and oxygen evolution methods in Lough Neagh, Northern Ireland. Proc R Irish Acad, 1977, 77B:87-99

9 Wetzel R G, ed. Limnology. Second edition. Fort Worth: Saunders College Publishing, 1983.565-558

10 Flint R W, et al. Adaptation of styrofoam substrate to benthic alage productivity studies in Lake Tahoe, Californis, Nevada. $J$ Phycol, 1977, 13:407-409

11 Grant I F, Egan E A \& Alexander M. Measurement of rates of grazing of the Ostracod Cyprinotus carolinensis on blue. Hydrobioiogia, 1983, 106:199-208

12 Andersen J M \& Sand Jensen K. Discrepancies between the $\mathrm{O}_{2}$ and ${ }^{14} \mathrm{C}$ methods for measuring phytoplankton gross photosynthesis at low light levels. OIKOS, 1980, 35:359-364

\title{
一种底栖蓝藻 ( Tolypothrix sp.) 的光合效率测定 ${ }^{*}$
}

\author{
陈宇炜 ${ }^{1}$ Martin Dokulil \\ (1: 中国科学院南京地理与湖泊破究所, 南京 210008; \\ 2: Institute of Limnology, A-5310 Mondsee. Austria)
}

提 要 底栖蓝藻( Tolypothrix sp.) 是一些底栖动物如介形虫的良好食物, 在自然状态下 呈丝状, 但经窒内培养后会形成很大的且难以分开的球形群体. 本研究着眼于这种蓝藻在室内培 养条件下的光合效率的测定,运用同位素 ${ }^{14} \mathrm{C}$ 方法和黑白瓶测氧法对不同光照强度和温度下它的 光合效率和呼吸率进行对比测定.结果表明，底栖蓝藻的光合效率随温度的提高而增加，但呼吸的 变化与温度没有明显的关系. 此蓝藻在光照强度低于 $400 \mu \mathrm{Em}^{-2} \mathrm{~s}^{-1}$ 时光合效率几乎不随光强的变 化而变化, 说明此底栖藻类对低光照强度的适应性. 比较同位素 ${ }^{14} \mathrm{C}$ 方法和黑白㼚测氧法的结果, 此蓝藻的光合效率比率为 1.11. 本砄究在对此类藻类的䂧究方法上有新的探索, 为此类底栖蓝藻 的生态学研究提供了可行的实验手段.

关键词 底栖蓝藻( Tolypothrix sp.) 光合效率 温度 光照强度
分类号 Q949.22

* 舆地利科学院湖泊研究所国际湖沼学培训班研究项目.

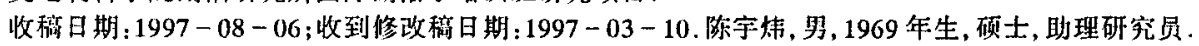

